\title{
STRATEGI PENGEMBANGAN SENTRA INDUSTRI KECIL MENENGAH PRODUKSI KRUPUK
}

\author{
M. Adhi Prasnowo ${ }^{1}$, Arif Khomaruddin ${ }^{2}$, Khoirul Hidayat ${ }^{3}$ \\ 1,2 Teknik Industri, Fakultas Teknik \\ Universitas Maarif Hasyim Latif, Sidoarjo, Indonesia \\ e-mail : ${ }^{1}$ prasnowoadhi@yahoo.co.id \\ 3 Teknologi Industri Pertanian, Fakultas Pertanian \\ Universitas Trunojoyo, Bangkalan, Indonesia
}

Diterima: 19 Maret 2017. Disetujui : 17 Mei 2017. Dipublikasikan : 1 Juni 2017

(C)2017 -TESJ Fakultas Teknik Universitas Maarif Hasyim Latif. Ini adalah artikel dengan akses terbuka di bawah lisensi CC BY 4.0 (https://creativecommons.org/licenses/by/4.0/)

\begin{abstract}
ABSTRAK
Pengembangan ekonomi kerakyatan merupakan strategi pembangunan yang menempatkan sector ekonomi rakyat sebagai sasaran utama pembangunan. Landasan ekonomi dalam negeri dengan sendirinya dapat terbangun dari perekonomian Indonesia akan mampu lebih mandiri, kokoh dan tidak tergantung dengan perekonomian luar negeri. Sesuai dengan pemikiran dan strategi di atas, maka arah kebijaksanaan ekonomi nasional perlu ditujukan pada sektor-sektor yang sarat dengan kepentingan rakyat, terkait dengan potensi dan kapasitas rakyat, serta sekaligus sesuai dengan sumber-sumber lokal sendiri yang tersedia. Dalam konteks ini sektor industri kecil merupakan salah satu alternatif yang dapat dipilih dan merupakan salah satu langkah untuk membangun ekonomi kerakyatan. Industri pembuatan kerupuk merupakan salah satu produk unggulan di Sidoarjo yang mempunyai potensi besar untuk dikembangkan. Hal ini dimungkinkan karena pembuatan kerupuk berdasarkan identifikasi dan pemilihan Klaster pengembangan ekonomi lokal (KPEL) mempunyai peranan yang benar dalam menciptakan kesempatan kerja, mengentaskan kemiskinan, dan distribusi pendapatan. Dari hasil penelitian yang ditunjukkan pada matriks QSPM yang didasarkan pada tiga alternatif strategi yang muncul pada tahap pencocokan (matching stage) yaitu penetrasi pasar, pengembangan pasar dan pengembangan produk dapat diketahui bahwa nilai tertinggi terletak pada strategi "meningkatkan kapasitas produksi" yaitu sebesar 7,380. Strategi meningkatkan kapasitas produksi ini agar bisa mencukupi kebutuhan pasar yang mengalami peningkatan, serta bisa menjaga persaingan yang semakin ketat.
\end{abstract}

Kata kunci : IKM Krupuk, Manajemen strategi, Pengembangan sentra industri kecil menengah.

\section{PENDAHULUAN}

Banyak ahli yang telah mendefinisikan tentang strategi. manajemen strategi adalah seni dan ilmu penyusunan, penerapan dan pengevaluasian keputusan-keputusan lintas fungsi (cross-functional) yang memberdayakan suatu organisasi untuk mencapai tujuannya. Oleh karenanya manajemen strategi berpusat pada penyatuan manajemen, pemasaran, keuangan/ akuntansi, produksi/operasi, riset dan pengembangan, serta sistem informasi komputer untuk mencapai keberhasilan organisasi. Strategi sebagai suatu proses penentuan rencana para pemimpin puncak yang berfokus pada tujuan jangka panjang organisasi, disertai penyusunan suatu cara atau upaya bagaimana agar tujuan tersebut dapat dicapai.
Selain itu strategi merupakan tindakan yang bersifat incremental (senantiasa meningkat) dan terus-menerus, serta dilakukan berdasarkan sudut pandang tentang apa yang diharapkan oleh para pelanggan di masa depan. Dengan demikian, strategi hampir selalu dimulai dari apa yang dapat terjadi dan bukan dimulai dari apa yang terjadi. Terjadinya kecepatan inovasi pasar yang baru dan perubahan pola konsumen memerlukan kompetensi inti (core competencies). Perusahaan perlu mencari kompetensi inti di dalam bisnis yang dilakukan. Secara menyeluruh (David, 2009) telah mengemukakan tahapan tentang analisis perumusan strategi seperti pada Gambar 1.

Tahap 1 dari kerangka perumusan terdiri atas matriks Evaluasi Faktor Eksternal (External Factor Evaluation, EFE), Matriks Evaluasi Faktor Internal (Internal Factor Evaluation, IFE), dan Matriks Profil Kompetitif (Compertitif Profil Matrix, 
CPM). Tahap 1, Tahap Input (Input Stage) berisi tentang informasi input dasar yang dibutuhkan untuk merumuskan strategi. Tahap 2, Tahap Pencocokan (Matching Stage), berfokus pada penciptaan alternatif strategi yang masuk akal dengan memperhatikan faktor-faktor eksternal dan internal utama. Teknik tahap 2 meliputi Matriks Kekuatan-Kelemahan-Peluang dan Ancaman (Strength-Weakness-Oportunity-Threats, SWOT), Matriks Posisi Strategis dan Evaluasi Tindakan (Strategic Position and Action Evaluation, SPACE), Matriks Boston Consultant Group (BCG), Matriks Internal-Eksternal (Internal-External Matrix), dan Matriks Strategi Besar (Giant Strategy Matrix), Tahap 3, Tahap Keputusan (Decision Stage), melibatkan satu teknik saja, Matriks Perencanaan Strategi Kuantitatif (Quantitatif Strategy Planning Matrix, QSPM) QSPM menggunakan informasi input dari Tahap 1 untuk secara objektif mengevaluasi strategi-strategi alternatif yang diidentifikasi dalam Tahap 2. QSPM menunjukkan daya tarik relatif berbagai strategi alternatif dan dengan demikian, memberikan landasan objektif bagi pemilihan strategi alternatif.

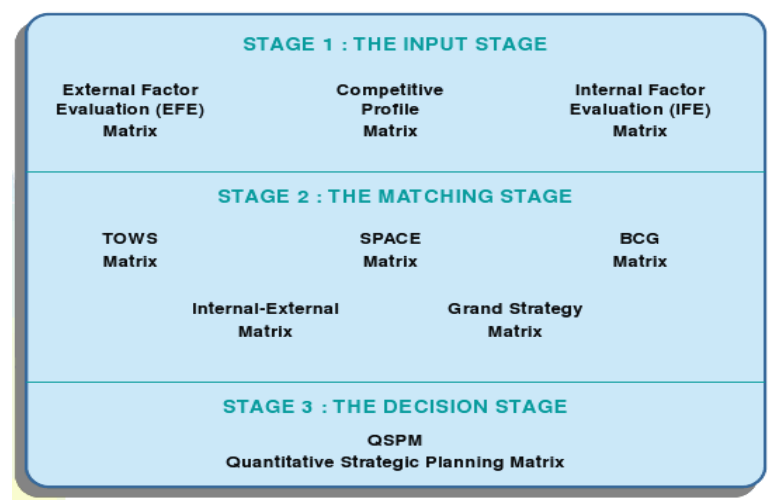

Gambar 1. Kerangka analitis perumusan strategi (David, 2009)

Pengembangan industri kecil dan menengah merupakan upaya perbaikan perekonomian karena potensinya yang sangat besar dalam menggerakkan perekonomian nasional. Industri kecil dan menengah mempunyai peranan yang besar pada perekonomian karena banyaknya masyarakat yang menggantungkan hidupnya pada IKM. Diantara usaha kecil dan menengah, industri kerupuk di desa Terik Kecamatan Krian Kabupaten Sidoarjo juga merupakan salah satu industri kecil yang ada di Indonesia.

Perhatian utama dalam penelitian ini adalah untuk melihat lebih jauh perkembangan dan keberadaan industri kerupuk di desa Terik Kecamatan Krian Kabupaten Sidoarjo, sehingga dapat dirumuskan strategi (skenario dan kebijakan) pengembangan yang akan digunakan dari penelitian ini adalah : Merumuskan strategi pengembangan sentra industri kecil dan menengah pembuatan kerupuk pada desa Terik Kecamatan
Krian Kabupaten Sidoarjo metode perumusan strategi pengembangan yang diaplikasikan pada penelitian ini menurut teori kerangka analogis perumusan strategi yang dikemukakan oleh Fred R. David.

\section{METODE PENELITIAN}

Penelitian ini menggunakan jenis penelitian studi kasus dengan mempelajari keadaan obyek penelitian secara intensif di Desa Terik Krian Sidoarjo. Penelitian ini memusatkan pada strategi pengembangan industri kecil pembuatan krupuk dengan melibatkan pihak-pihak terkait. Metode kerangka perumusan strategi yang diaplikasikan pada penelitian ini sebagai upaya untuk merumuskan strategi yang akan direkomendasikan sesuai teori yang dikemukakan oleh Fred R David terdiri dari beberapa tahapan, antara lain dapat dijelaskan tahap 1 dari kerangka perumusan terdiri atas matriks evaluasi eksternal (Eksternal Factors Evaluation EFE). Matriks evaluasi factor internal (Internal Factors Evaluation, IFE) dan matriks profil kompetitif (Competitive Profil Matrix CPM).

Tahap 1 tahap input (Input stage) berisi tentang informasi input dasar yang dibutuhkan untuk merumuskan strategi. Tahap 2 pencocokan (Matching stage). Berfokus pada penciptaan alternatif strategi yang masuk akal dengan memperhatikan factor-faktor eksternal dan internal utama. Teknik tahap 2 meliputi matriks kekuatan kelemahan, peluang dan ancaman (strength-weakness-opportunity-threats, SWOT), matriks posisi strategis dan evaluasi tindakan (strategis position and action evaluation, SPACE), matriks Boston Consultant Group (BCG), matriks internal, eksternal (Internal - eksternal matriks), dan matriks strategi besar (Giant strategy matriks). Tahap 3 tahap keputusan (Decision stage), melibatkan satu teknik saja, matriks perencanaan strategi kuantitatif (Quantitative strategy planning matrik, QSPM) QSPM menggunakan informasi input dari tahap 1 untuk secara obyektif mengevaluasi strategi-strategi alternative yang diidentifikasi dalam tahap 2 QSPM menunjukkan daya tarik relative berbagai strategi dan dengan demikian, memberikan landasan obyektif bagi pemilihan strategi alternatif.

Pada masing-masing tahap untuk penentuan skor bobot menggunakan metode binary dominance matrix dengan data yang digunakan adalah dari proses teknik focuss group discussion, penggunaan teknik tersebut adalah karena usulan kebijakan strategi mengarah ke sentra produksi sehingga keputusan focuss group discussion sudah bisa mewakili dari anggota sentra paguyuban. 


\section{HASIL DAN PEMBAHASAN}

Pembuat kerupuk atau pengusaha kerupuk di Desa Terik dulu sedikit, kurang lebih ada 5 pengusaha. Krupuk yang dibuatpun juga sangat sederhana misalnya kerupuk tahu dan kerupuk puli saja. Kemudian dengan berjalannya waktu para penguasa mengembangkan usahanya masingmasing, dengan membuat kerupuk mawar yang sedang tenar di pasaran saat itu sampai sekarang. Setelah melihat tetangganya banyak yang sukses dengan usaha kerupuk maka sekarang banyak yang menekuni usaha kerupuk di Desa Terik. Pada tahap pembahasan, proses perumusan strategi dilakukan dengan beberapa tahapan, meliputi : input stage, matching stage dan decision stage. Pada masingmasing tahapan dilakukan proses focus group discussion dan wawancara untuk memperoleh seluruh data pendukung dalam menentukan rekomendasi rumusan strategi.

Pada tahap input, dilakukan beberapa kegiatan sebagai upaya untuk memenuhi informasi dasar yang dibutuhkan untuk merumuskan strategi. Adapun kegiatan-kegiatan yang dilakukan antara lain : penilaian faktor eksternal (Eksternal Factors Evaluation), identifikasi profil pesaing dan penilaian faktor internal (Internal Factors Evaluation).

Tabel 1. Daftar informasi faktor-faktor yang dikategorikan dalam informasi peluang IKM pembuatan kerupuk

\begin{tabular}{|llcc|}
\hline No & \multicolumn{1}{c}{ Faktor-Faktor } & $\begin{array}{c}\text { Teknis/Non- } \\
\text { Teknis }\end{array}$ & $\begin{array}{c}\text { Simbol } \\
\text { Faktor }\end{array}$ \\
\hline 1. $\begin{array}{l}\text { Kebijakan ketua paguyuban } \\
\text { menentukan harga barang } \\
\text { yang sesuai pasar }\end{array}$ & Teknis & A \\
\hline 2. $\begin{array}{l}\text { Banyak masyarakat yang } \\
\text { mencoba untuk membuat } \\
\text { kerupuk }\end{array}$ & Bon-Teknis \\
\hline 3. $\begin{array}{l}\text { pangsa pasar dalam negeri } \\
\text { yang terbuka }\end{array}$ & Teknis & $\mathrm{C}$ \\
\hline 4. $\begin{array}{l}\text { Antusias masyarakat untuk } \\
\text { memasarkan kerupuk pada } \\
\text { daerah lain }\end{array}$ & Don-Teknis \\
\hline 5. $\begin{array}{l}\text { Adanya pusat pelatihan } \\
\text { pengembangan usaha kerupuk }\end{array}$ & Teknis \\
\hline 6. $\begin{array}{l}\text { selera masyarakat pada } \\
\text { camilan kerupuk yang semakin } \\
\text { meningkat }\end{array}$ & Non-Teknis \\
\hline
\end{tabular}

Penilaian faktor eksternal merupakan kegiatan yang dilakukan untuk memperoleh informasi tentang peluang dan ancaman IKM Pembuat kerupuk Desa Terik terhadap produk dan kelangsungan bisnisnya. Informasi-informasi tersebut merupakan faktor yang menjadi alat ukur untuk melakukan penilaian. Penentuan faktorfaktor untuk menjadi alat ukur penilaian ditentukan dengan cara proses wawancara dan diskusi yang melibatkan pihak-pihak yang menguasai dalam bidang pembuatan kerupuk, antara lain : Ketua paguyuban, pengusaha, konsumen dan peneliti. Dari hasil diskusi dan wawancara diperoleh informasi mengenai faktorfaktor yang menjadi alat ukur, faktor-faktor tersebut meliputi hal yang bersifat teknis dan hal yang bersifat non-teknis antara lain :

Dari Tabel 1 dan Tabel 2 informasi faktorfaktor di atas selanjutnya dilakukan analisis dengan menggunakan matriks evaluasi faktor eksternal. Pada matriks tersebut penilaian didasarkan atas penentuan bobot faktor (dapat dilihat pada lampiran perhitungan binary dominance matrix evaluasi faktor eksternal) dan rating factor dengan data diambil dari kegiatan focus group discussion. Dari hasil perhitungan di peroleh total skor bobot untuk matriks evaluasi eksternal adalah sebesar 3,690909. Hasil skor bobot tersebut menunjukkan bahwa sentra UKM pembuatan kerupuk dapat secara efektif memanfaatkan peluang yang ada untuk meminimalkan tingkat ancaman. Dengan bobot terbesar faktor peluang terdapat pada faktor "Selera masyarakat pada camilan kerupuk yang meningkat" sebesar 0,181818 dan bobot terbesar faktor peluang terdapat pada faktor "Produk yang sama" sebesar 0,090909. Dilihat dari sifat faktor eksternal yang berhubungan secara langsung (teknis) atau tidak berhubungan langsung (non teknis) bobot terbesar terdapat pada faktor yang bersifat teknis, untuk kategori ancaman dan bobot terbesar terdapat pada faktor yang bersifat non teknis untuk kategori peluang.

Tabel 2. Daftar informasi faktor-faktor yang dikategorikan dalam informasi ancaman IKM pembuat krupuk

\begin{tabular}{|c|c|c|c|}
\hline No & Faktor-Faktor & $\begin{array}{l}\text { Teknis/Non- } \\
\text { Teknis }\end{array}$ & Simbol Faktor \\
\hline 1. & Masuknya produk dari daerah lain & Non-Teknis & G \\
\hline 2. & Produk yang sama & Non-Teknis & $\mathrm{H}$ \\
\hline & $\begin{array}{l}\text { Harga bahan baku yang terus } \\
\text { mengalami kenaikan }\end{array}$ & Teknis & I \\
\hline & $\begin{array}{l}\text { Berkurangnya jumlah pekerja } \\
\text { yang ahli }\end{array}$ & Teknis & $\mathrm{J}$ \\
\hline & $\begin{array}{lll}\begin{array}{l}\text { Kawasan } \\
\text { penduduknya }\end{array} & \text { yang } & \text { padat }\end{array}$ & Non-Teknis & K \\
\hline
\end{tabular}

Proses analisis profil pesaing pada tahap ini diolah dengan menggunakan competitive profile matrix, matriks tersebut mengidentifikasi pesaingpesaing utama suatu perusahaan serta kekuatan dan kelemahan khusus mereka dalam hubungannya dengan posisi strategis perusahaan pesaing.

Tabel 3. Daftar informasi faktor-faktor penting keberhasilan

\begin{tabular}{|cl|}
\hline No & Faktor-Faktor Penting Keberhasilan \\
\hline 1. & Pangsa Pasar \\
\hline 2. & Harga Jual Produk \\
\hline 3. & Sistem manajemen organisasi \\
\hline 4. & Kualitas Produk \\
\hline 5. & Kapasitas Produksi \\
\hline 6. & Loyalitas Konsumen \\
\hline
\end{tabular}


Tabel 4. Pesaing IKM pembuat kerupuk

\begin{tabular}{|cl|}
\hline No & Pesaing IKM pembuat kerupuk \\
\hline 1. & Kerupuk Desa Kandangan \\
\hline 2. & Kerupuk Kec Tulangan \\
\hline 3. & Krupuk Desa Krembung \\
\hline
\end{tabular}

Penentuan pesaing dan faktor-faktor penting keberhasilan dilakukan dengan melakukan survei lapangan dan focus group discussion dengan responden yang telah ditentukan. Dengan hasil seperti yang ditampilkan pada Tabel 3 dan Tabel 4.

Dari hasil focus group discussion dan perhitungan yang dilakukan dapat dijelaskan sebagai berikut:

1. Bobot terbesar pada faktor-faktor penting keberhasilan adalah "kapasitas produksi" dengan bobot sebesar 0,26. Bobot kedua adalah “ harga jual produk " dan " kualitas produk " dengan bobot sebesar 0,20.

2. Ketiga profil pesaing yang telah diidentifikasi, menunjukkan bahwa produk Kerupuk dari Kec. Tulangan merupakan pesaing utama dengan nilai bobot sebesar 3,53. Dan yang menjadi pengikut adalah kerupuk Desa Kandangan.

3. Kondisi lapangan untuk kerupuk Desa Kandangan tidak berdampak signifikan terhadap pasar kerupuk Desa Terik, dikarenakan bentuk kerupuk Desa Terik tidak mudah ditiru. Pasar cenderung bersaing dengan produk lokal terutama produk kerupuk Desa Krembung.

Penilaian faktor internal merupakan kegiatan yang dilakukan untuk memperoleh informasi tentang kekuatan dan kelemahan yang dimiliki oleh suatu jenis usaha. Informasi-informasi tersebut merupakan faktor yang menjadi alat ukur untuk melakukan penilaian. Penentuan faktorfaktor untuk menjadi alat ukur penilaian ditentukan dengan cara proses wawancara dan diskusi yang melibatkan pihak-pihak yang menguasai dalam bidang pembuatan kerupuk, antara lain : Ketua paguyuban, pengusaha, konsumen dan peneliti.

Tabel 5. Daftar informasi faktor-faktor yang dikategorikan dalam informasi kekuatan IKM pengusaha kerupuk

\begin{tabular}{|cllc|}
\hline No & \multicolumn{1}{c}{ Faktor-Faktor } & $\begin{array}{c}\text { Teknis/Non- } \\
\text { Teknis }\end{array}$ & Simbol Faktor \\
\hline 1. & Terdapat kawasan sentra produksi & Teknis & A \\
\hline 2. & Memberi wama yang cerah & Teknis & B \\
\hline 3. & $\begin{array}{l}\text { Terdapat paguyuban yang } \\
\text { menaungi pembuat kerupuk }\end{array}$ & Teknis & C \\
\hline 4. & Kualitas yang baik & Teknis & D \\
\hline 5. & Telah mempunyai konsumen setia & Non-Teknis & E \\
\hline 6. & Akses transportasi yang mudah & Non-Teknis & F \\
\hline 7. & Harga yang relatif terjangkau & Teknis & G \\
\hline
\end{tabular}

Dari hasil focus group discussion diperoleh informasi mengenai faktor-faktor yang menjadi alat ukur, faktor-faktor tersebut meliputi hal yang bersifat teknis dan hal yang bersifat non-teknis antara lain ditampilkan pada Tabel 5 dan Tabel 6 .

Dari hasil perhitungan diperoleh bahwa total skor bobot untuk matriks evaluasi internal adalah sebesar 3,090892. Hasil skor bobot tersebut menunjukkan bahwa sentra UKM kerupuk Desa

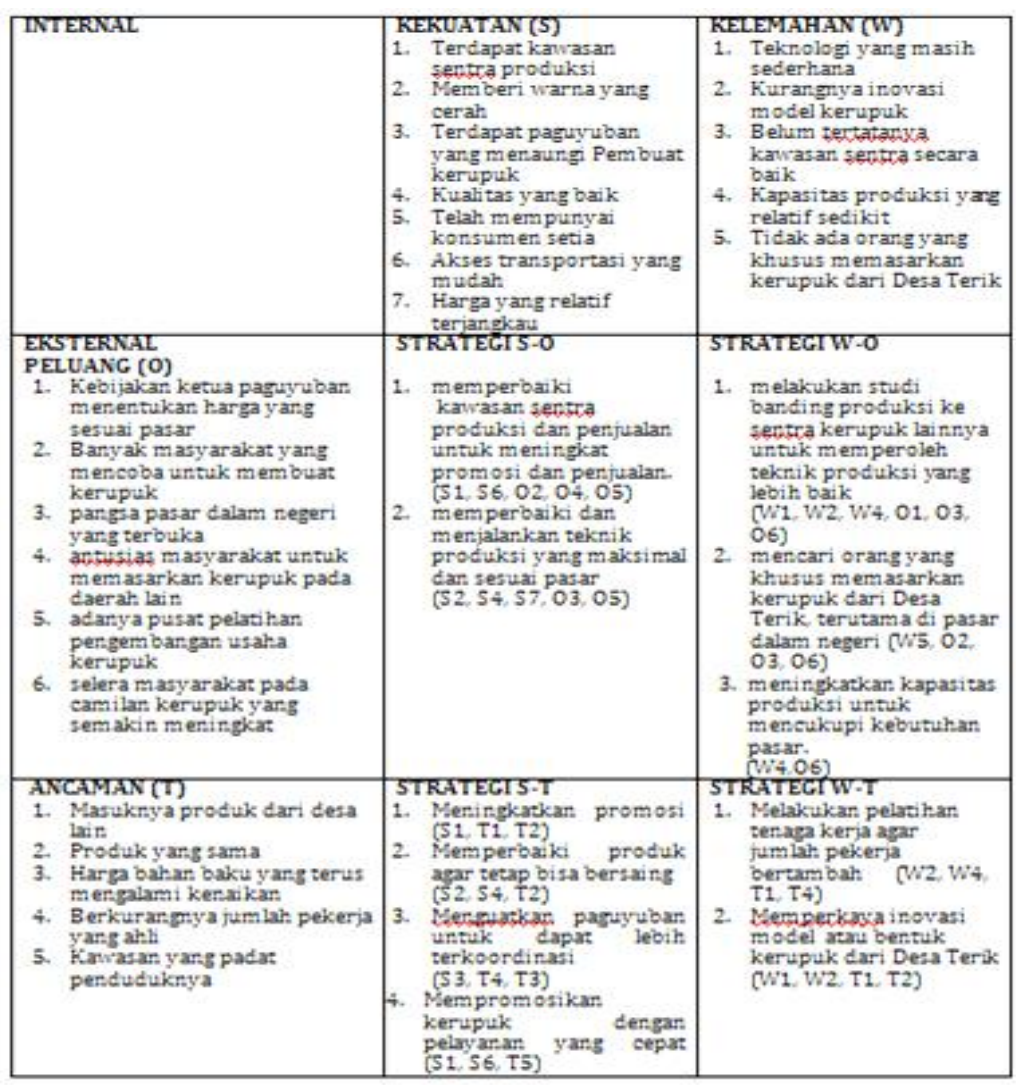

Gambar 2. Matriks SWOT untuk IKM pembuat kerupuk di desa Terik 
Terik dapat secara efektif memanfaatkan kekuatan yang ada untuk meminimalkan tingkat kelemahan. Dengan bobot terbesar faktor kekuatan terdapat pada faktor " terdapat kawasan sentra produksi" sebesar 0,166667 dan bobot terbesar faktor kelemahan terdapat pada faktor " kurangnya inovasi model kerupuk" sebesar 0,090909. Dilihat dari sifat faktor internal yang berhubungan secara langsung (teknis) atau tidak berhubungan langsung (non teknis) bobot terbesar terdapat pada faktor yang bersifat teknis, untuk faktor kekuatan dan bobot terbesar terdapat pada faktor yang bersifat teknis, untuk kategori kelemahan.

Tabel 6. Daftar informasi faktor-faktor yang dikategorikan dalam informasi kelemahan IKM pengusaha kerupuk

\begin{tabular}{|c|c|c|c|}
\hline No & Faktor-Faktor & $\begin{array}{l}\text { Teknis/Non- } \\
\text { Teknis }\end{array}$ & Simbol Faktor \\
\hline 1. & Teknologi yang masih sederhana & Teknis & $\mathrm{H}$ \\
\hline 2. & Kurangnya inovasi model kerupuk & Teknis & I \\
\hline 3. & $\begin{array}{l}\text { Belum tertatanya kawasan sentra } \\
\text { secara baik }\end{array}$ & Non-Teknis & $\mathrm{J}$ \\
\hline 4. & $\begin{array}{l}\text { Kapasitas produksi yang relatif } \\
\text { sedikit }\end{array}$ & Teknis & $\mathrm{K}$ \\
\hline & $\begin{array}{l}\text { Tidak ada orang yang khusus } \\
\text { memasarkan kerupuk dari } \\
\text { kawasan sentra IKM Terik }\end{array}$ & Non-Teknis & L \\
\hline
\end{tabular}

Tahap pencocokan merupakan langkah untuk mengembangkan alternatif-alternatif strategi yang diolah ke dalam beberapa matriks berdasarkan pada faktor-faktor eksternal dan faktor-faktor internal. Matriks SWOT adalah sebuah alat pencocokan yang penting untuk membantu para manajer mengembangkan empat jenis strategi, yaitu : strategi SO (kekuatanpeluang), strategi WO (kelemahan-peluang), strategi ST (kekuatan-ancaman), strategi WT (kelemahan-ancaman).

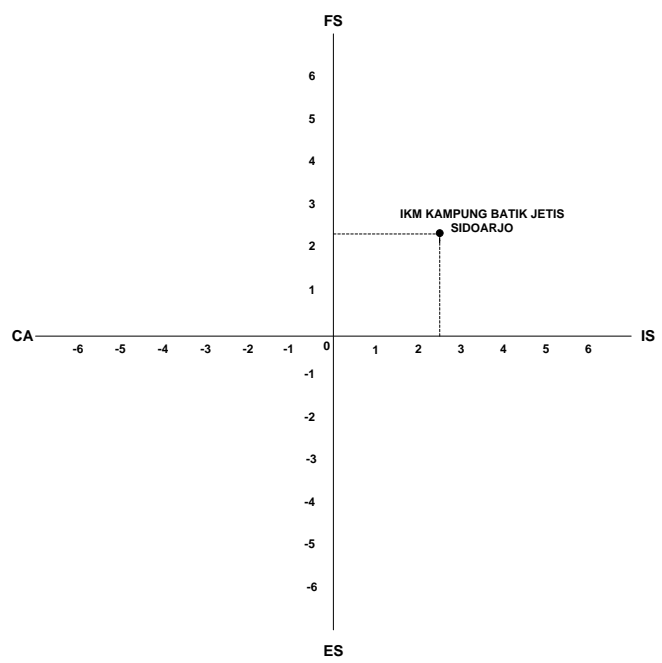

Gambar 3. Grafik posisi IKM pembuat kerupuk di desa Terik

Matriks SPACE merupakan kerangka empat kuadran yang menunjukkan alternatif strategi yang akan dilaksanakan oleh IKM pembuat kerupuk Di
Desa Terik, strategi empat kuadran tersebut terdiri dari : strategi agresif, strategi konservatif, strategi defensif, strategi kompetitif. Dari hasil pengolahan selanjutnya dapat diketahui alternatif strategi yang cocok untuk IKM pembuat kerupuk di Desa Terik.

Dari grafik Gambar 3 dapat diketahui bahwa posisi IKM pembuat kerupuk di Desa Terik terletak pada kuadran agressive. Dikarenakan kuadran tersebut pada faktor Financial Strength dan Internal Strength yang dapat dikatakan masih dalam keadaan kurang.

Pada pengolahan dalam matriks BCG, data diperoleh data dari data sekunder dan focus group discussion bersama tim.

Dari hasil pengolahan matriks BCG Gambar 4 dapat dijelaskan bahwa seluruh produk kerupuk terletak pada posisi kuadran II " BINTANG " hal ini berarti kerupuk Desa Terik dapat menggunakan strategi penetrasi pasar, pengembangan pasar dan pengembangan produk. Kemudian alternatif teknis yang dapat dilakukan sesuai dengan keadaan dan kondisi adalah dengan:

1. Melakukan penetrasi pasar dengan menaikkan kapasitas produksi terlebih dahulu agar pasar lebih banyak mengetahui produk kerupuk Desa Terik.

Adapun teknis dalam rangka menaikkan kapasitas produksi adalah :

a. Memperbaiki tempat produksi ataupun fasilitas produksi

b. Memperbanyak jumlah pekerja yang ahli

c. Melakukan studi banding ke daerah penghasil kerupuk lainnya untuk memperoleh metode produksi baru.

2. Mengembangkan produk dengan memperbanyak model atau memperbaiki metode kerja yang ada.

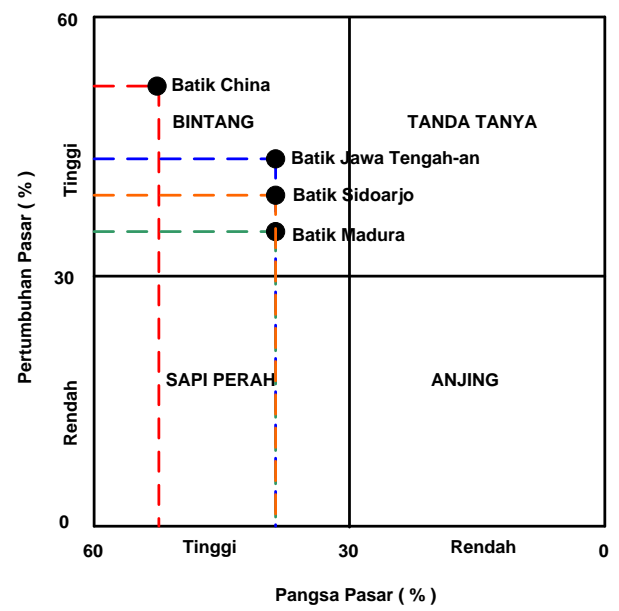

Gambar 4. Matriks Boston Consulting Group untuk produk kerupuk

Dari alternatif teknis strategi-strategi di atas diharapkan kerupuk Desa Terik pada awalnya hanya menaikkan prosentase pangsa pasar dan 
selanjutnya mengarah ke strategi pengembangan pasar.

Pengolahan yang dilakukan pada fase matriks strategi besar didasarkan pada data posisi kom petitif dan pertumbuhan pasar produk krupuk Desa Terik. Posisi kompetitif dapat dilihat pada matriks CPM, produk krupuk Desa Terik memiliki nilai 3,20 yang berada pada posisi ketiga dari 4 produk yang ada. Sedangkan untuk pertumbuhan pasar memiliki prosentase $40 \%$ hal ini menunjukkan adanya pertumbuhan yang sangat baik, dilihat dari matriks BCG. Dari hasil pengolahan dapat diketahui bahwa produk kerupuk Desa Terik berada pada kuadran I, sesuai dengan kondisi internal IKM maka alternatif strategi yang dapat diaplikasikan adalah dengan penetrasi pasar, pengembangan pasar dan produk. Dengan kondisi di atas alternatif teknis strategi yang dapat diaplikasikan adalah dengan memperkuat posisi kompetitif produk terlebih dahulu sehingga dalam upaya pengembangan pasar di tahap selanjutnya akan lebih mudah.

Tahap keputusan Pengolahan data yang dilakukan pada matriks perencanaan strategi kuantitatif (matriks QSPM), menggunakan analisis penggabungan pada setiap tahap sehingga alternatif perumusan strategi yang ditentukan merupakan hasil pengolahan dari tahap-tahap sebelumnya. Strategi yang dapat diaplikasikan mengarah kepada penetrasi pasar, pengembangan pasar dan pengembangan produk. Sehingga alternatif strategi yang akan diseleksi antara lain :

1. Meningkatkan kapasitas produksi, landasan pemilihan alternatif strategi adalah :

a. Sebagai upaya untuk memenuhi kebutuhan pasar yang masih terbuka

b. Mengambil peluang persaingan

2. Mendidik tenaga kerja baru, landasan pemilihan alternatif strategi adalah :

a. Semakin berkurangnya jumlah tenaga kerja

b. Permintaan pasar yang semakin meningkat

c. Meningkatkan kapasitas produksi

3. Melakukan inovasi model yang lebih beragam

a. Semakin banyaknya produk pesaing

b. Memperkaya jenis model kerupuk

Dari hasil pengolahan matriks QSPM yang didasarkan pada tiga alternatif strategi yang muncul pada tahap pencocokan (matching stage) yaitu penetrasi pasar, pengembangan pasar dan pengembangan produk dapat diketahui bahwa nilai tertinggi terletak pada strategi "mencari orang yang khusus menjual kerupuk Desa Terik" yaitu sebesar 7,079. Strategi mencari orang yang khusus menjual kerupuk Desa Terik. Strategi ini berusaha untuk dapat memberikan penetrasi pasar dan pengembangan pasar dikarenakan dengan adanya orang yang khusus menjual atau memasarkan kerupuk dari Desa Terik sehingga harga dan persaingan di pasaran tetap bisa terjaga.

\section{PENUTUP}

Berdasarkan hasil penelitian, pembahasan untuk memperoleh rekomendasi strategi pengembangan sentra industri kecil menengah pembuatan krupuk pada Desa Terik dan memenuhi tujuan penelitian, maka dapat disimpulkan sebagai berikut :

1. Pada tahap Input Stage

Pada tahap input diperoleh perhitungan data yang menunjukkan nilai evaluasi faktor eksternal, nilai posisi kompetitif usaha dibandingkan dengan pesaing usaha dan nilai evaluasi faktor internal. Nilai EFE memungkinkan IKM produksi krupuk Desa Terik berada pada tingkat yang sangat memungkinkan memanfaatkan peluang untuk meminimalkan ancaman yang ada, ditunjukkan dengan skor bobot sebesar 3,690909 yang berarti IKM berada dalam kondisi responsif ditinjau dari skala 1-4. Nilai IFE yang ditunjukkan sebesar 4,090892 juga mengindikasikan bahwa IKM produksi krupuk Desa Terik berada dalam kondisi responsif untuk memanfaatkan faktor kekuatan sebagai upaya meminimalkan faktor kelemahan yang dimiliki. Dari CPM menunjukkan posisi krupuk Desa Terik sebagai pemimpin pasar, krupuk Desa Terik dapat menerapkan strategi dengan meningkatkan penetrasi pasar dan pengembangan pasar.

2. Pada tahap Matching Stage

Pada tahap pembentukan matriks SWOT diperoleh alternatif-alternatif strategi seperti ditunjukkan pada tabel 4.21. Pada tahap matriks SPACE IKM produksi krupuk Desa Terik berada pada posisi strategi kuadran agressive dengan nilai $\mathrm{FS}=4,75 ; \mathrm{CA}=-2,67 ; \mathrm{ES}=-2,33$ dan IS = 5, sehingga alternatif strategi yang dapat dilakukan adalah dengan penetrasi pasar, pengembangan pasar dan pengembangan produk. Pada tahap matriks Boston Consulting Group (Matriks BCG) Posisi krupuk Desa Terik ada pada kuadran bintang yang berarti bahwa menggambarkan peluang pertumbuhan dan profitabilitas jangka panjang yang baik. alternatif strategi yang dapat diterapkan antara lain : penetrasi pasar, pengembangan pasar dan pengembangan produk. Pada tahap Matriks Internal - Eksternal Diketahui skor bobot total pada matriks IFE dan EFE menunjukkan bahwa posisi "tumbuh dan membangun" alternatif strategi yang dapat diaplikasikan adalah dengan strategi yang intensif antara lain : penetrasi pasar, pengembangan pasar dan pengembangan produk. Pada tahap Matriks Strategi Besar (Matriks TGS), dari hasil 
pengolahan dapat diketahui bahwa produk krupuk Desa Terik berada pada kuadran I, sesuai dengan kondisi internal IKM maka alternatif strategi yang dapat diaplikasikan adalah dengan penetrasi pasar, pengembangan pasar dan produk.

3. Pada tahap keputusan (Decision Stage)

Dari hasil pengolahan matriks QSPM yang didasarkan pada tiga alternatif strategi yang muncul pada tahap pencocokan (matching stage) yaitu penetrasi pasar, pengembangan pasar dan pengembangan produk dapat diketahui bahwa nilai tertinggi terletak pada strategi "meningkatkan kapasitas produksi“ yaitu sebesar 7,380.

Strategi meningkatkan kapasitas produksi ini agar bisa mencukupi kebutuhan pasar yang mengalami peningkatan, serta bisa menjaga persaingan yang semakin ketat.

\section{DAFTAR PUSTAKA}

Anoraga, P., \& Sudantoko, H.D. (2002). Koperasi, kewirausahaan, dan usaha kecil. Penyalur tunggal, Rineka Cipta.

David, F. R. (2009). Strategic Management: Manajemen Strategis Konsep Buku 1-12/E.

Hurst, K. (2006). Prinsip-Prinsip Perancangan Teknik. Erlangga. Jakarta.

Kurniawati, T., \& Sari K B, D. K. (2011). Analisis dan Pilihan Strategi: Membangun Esksistensi Perusahaan di Masa Krisis. Ekonomi Bisnis, $14(3)$.

Leary, J. (2008). Design of a Novel Product Using Waste Material. Department of Mechanical Engineering, The University of Sheffield.

Prasnowo, A. (2008). Perancangan Produk dengan Metode Pembobotan Kriteria dan Pemilihan Konsep Menggunakan Binary Dominance Matrix, Fakultas Teknik, Jurusan Teknik Industri, Universitas Trunojoyo.
Rini, E.S. (2002). Mengenal Pesaing dan Intesitas Persaingan. Publikasi Ilmiah, Fakultas Ekonomi, Jurusan Manajemen Ekonomi, Universitas Sumatra Utara.

Soetrisno, N. (2002). Pengembangan UKM, Ekonomi Rakyat Dan Penanggulangan Kemiskinan. Jakarta.

Wijaya, K. (2002). Analisis Pemberdayaan Usaha Kecil. Pustaka Wirausaha Muda. Bogor.

Zinn, L., \& Power, C. (1992). Move Over, Boomers: The Busters are Here-and They're Angry'. Business Week, 329, 74-82. 
MA Prasnowo, dkk / Teknika, Vol. 1, No.1, Juni 2017, 17-24

Halaman ini sengaja dikosongkan 